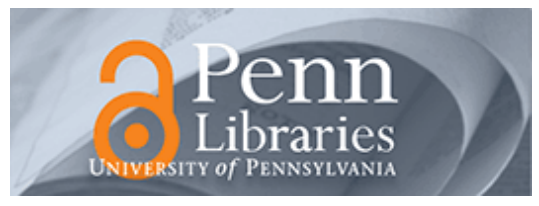

University of Pennsylvania

ScholarlyCommons

Management Papers

Wharton Faculty Research

$1-2015$

\title{
Are Incentives Without Expertise Sufficient? Evidence From Fortune 500 Firms
}

Emilie R. Feldman

University of Pennsylvania

Cynthia A. Montgomery

Follow this and additional works at: https://repository.upenn.edu/mgmt_papers

Part of the Business Administration, Management, and Operations Commons

\section{Recommended Citation}

Feldman, E. R., \& Montgomery, C. A. (2015). Are Incentives Without Expertise Sufficient? Evidence From Fortune 500 Firms. Strategic Management Journal, 36 (1), 113-122. http://dx.doi.org/10.1002/smj.2211

This paper is posted at ScholarlyCommons. https://repository.upenn.edu/mgmt_papers/37

For more information, please contact repository@pobox.upenn.edu. 


\title{
Are Incentives Without Expertise Sufficient? Evidence From Fortune 500 Firms
}

\author{
Abstract \\ Agency theory predicts that incentives will align agents' interests with those of principals. However, the \\ resource-based view suggests that to be effective, the incentive to deliver must be paired with the ability \\ to deliver. Using Fortune 500 boards as an empirical context, this study shows that the presence of \\ directors who lack top-level experience but own large shareholdings is negatively associated with firm \\ value, an effect that increases in the number of such directors. Firm value rises after such directors \\ depart from boards, with the greatest increases occurring when many of these directors leave. While \\ agency theory highlights the importance of the right incentives being in place, this research suggests that \\ this can be ineffective if the right resources are not also in place. \\ Keywords \\ agency theory, resource-based view, capabilities, incentives, expertise \\ Disciplines \\ Business Administration, Management, and Operations
}




\title{
Are Incentives Without Expertise Sufficient? Evidence from Fortune 500 Firms*
}

\author{
Emilie R. Feldman \\ The Wharton School \\ University of Pennsylvania \\ feldmane@wharton.upenn.edu \\ +1-215-746-7676 \\ Cynthia A. Montgomery \\ Harvard Business School \\ cmontgomery@hbs.edu \\ +1-617-495-6991
}

\begin{abstract}
Agency theory predicts that the right incentives will align agents' interests with those of principals. However, the resource-based view suggests that to be effective, the incentive to deliver must be paired with the ability to deliver. Without requisite ability, an agent's incentives may yield the desired alignment but not the desired results. Using the corporate boards of Fortune 500 firms as an empirical context, this study shows that the presence of directors who lack top-level business experience but have large ownership stakes is negatively associated with firm value, an effect that becomes larger as the number of such directors on a board increases. Furthermore, firm value rises after such directors depart from corporate boards, with the greatest increases occurring in firms where the reduction in the number of these directors is the largest. While agency theory highlights the importance of having the right incentives in place, this research suggests that doing so can be ineffective if the right resources are not in place as well.
\end{abstract}

Keywords: agency theory, resource-based view, capabilities, incentives, expertise

Strategic Management Journal, 36(1): 113-122

\footnotetext{
* We would like to thank Elizabeth Beiser, David Chen, Sally Luo, Garrett Marsilio, Tong Sun, Hue Vuong, and Lawrence Yen for excellent research assistance. We are grateful to Juan Alcácer, Raffi Amit, Olivier Chatain, Stuart Gilson, Mauro Guillén, Martine Haas, Connie Helfat, Felix Oberholzer, Harbir Singh, Belén Villalonga and Birger Wernerfelt for their very helpful suggestions on earlier drafts of this paper. We also appreciate the comments of seminar participants at Harvard Business School, London Business School, and the 2009 Academy of Management Conference in Chicago, IL. We gratefully acknowledge the Center for Leadership and Change Management at The Wharton School and the Division of Research at Harvard Business School for its generous financial support of this research. Any errors are our own.
} 


\section{Introduction}

It seems obvious that one should not delegate a decision to someone who is incompetent, but there is not a lot of business research consistent with this view. There are two reasons for this - the prevailing influence of agency theory, according to which effective decision-making can be promoted by giving agents the right incentives; and the expectation that firms would avoid delegating decisions to unqualified people, such that this counterfactual may not appear frequently in real-world data. Bridging these ideas, this paper examines the question of whether strong incentives in the absence of expertise are sufficient to produce favorable results. We address this issue using data from the boards of Fortune 500 firms. This context is a useful one because it allows us to exploit the fact that some individuals may have come to strong incentives (and board seats) through historical precedent, inheritance, or corporate ties rather than expertise, yielding directors with strong incentives to perform but weak capabilities to do so.

While one might expect such incidences to be relatively rare, the business press and corporate histories suggest otherwise. In 2007, for example, News Corp announced the appointment of Natalie Bancroft to its board. The Wall Street Journal gave this account: "Instead of the seasoned newspaper veteran some family members and many journalists had hoped for, the family's representative will be Natalie Bancroft, a 27-year-old opera singer living in Europe who, by her own admission, is a relative neophyte to the worlds of both journalism and commerce.” Other examples might include small-town bankers who, through a string of consolidations, end up as directors of some of the world's largest corporations, or local business associates who joined a board in a company’s earlier, humbler years, and have never left.

Agency theory would predict that share ownership in the hands of such directors would align their interests with those of other shareholders, making them effective monitors of top 
management and more likely to make value-maximizing decisions, both of which should enhance firm value (Berle and Means, 1932; Jensen and Meckling, 1976). However, this perspective does not account for the possibility that agents' incentives may not produce their expected benefits for principals if the agents lack the expertise that strong performance requires.

The resource-based view (Wernerfelt, 1984) holds that the expertise of a firm’s managers constitutes a scarce and heterogeneous strategic resource that productively interacts with a firm's other key resources to generate rents (Penrose, 1959; Castanias and Helfat, 1991; Harris and Helfat, 1997). Directors' expertise, too, has been shown to be positively associated with performance (Westphal and Frederickson, 2001; McDonald, Westphal, and Graebner, 2008).

Together, these theories imply that incentives combined with expertise are a beneficial pair of characteristics for both managers and directors. Kroll, Walters, and Wright (2008) found evidence consistent with this idea, showing that the interaction between directors' acquisition experience and their financial incentives is positively associated with acquisition returns.

This paper considers the inverse relationship: the association between firm value and the presence of directors who have strong incentives to maximize firm value but may lack the requisite business expertise to do so. We argue that this combination of characteristics does not simply revert to agency theory's predicted positive relationship between incentives and performance. Instead, we expect that such directors' lack of expertise may limit their ability to monitor management and undermine the benefits of incentive alignment. Further, the presence of such directors may also impose an opportunity cost on firms by preventing them from employing other directors who could better fulfill the responsibilities. Thus, we expect that the presence of such directors on boards may be associated with lower, not higher, firm value. 
We investigate this prediction using a proprietary dataset of the directors serving on the boards of public Fortune 500 firms between 2004 and 2010. We document a negative association between firm value and the presence of directors who hold significant ownership stakes but lack high-level expertise, a relationship that worsens in the number of these directors on a board. We also show that firm value increases when such directors depart from firms’ boards.

Management research has devoted considerable effort to investigating how managers’ and directors' capabilities may enhance their effectiveness, enabling them to contribute in a positive way to their firms. Here, we explore a situation where a lack of expertise appears to work against a firm, even in the presence of strong incentives. These results are consistent with the view that incentives and resources are interdependent. Focusing on one without the other may give a distorted view of behavior, and expectations that are inconsistent with outcomes.

\section{Theory and Hypotheses}

What is the role of a board of directors? Agency theory sees boards as a means to resolve or mitigate agency problems between managers and shareholders (Berle and Means, 1932). Resource dependence theory (Pfeffer and Salancik, 1978; Hillman and Dalziel, 2003) and the resource-based view (Penrose, 1959; Castanias and Helfat, 1991) focus on the skills and expertise of directors as resources for their firms.

A premise of agency theory is that diffuse equity ownership makes the monitoring and oversight of management costly, increasing the likelihood that managers will engage in valuedestroying activities such as shirking or perquisite consumption (Jensen and Meckling, 1976). Outside directors mitigate agency problems by monitoring managers to ensure they do not engage in such behavior, and in turn, equity ownership strengthens outside directors' incentives to monitor management (Kosnik, 1987; Johnson, Hoskisson, and Hitt, 1993). 
Alongside this perspective, resource-dependence theory (Pfeffer and Salancik, 1978) suggests that directors, especially those who are independent of management, could be resources for their companies, providing "capital" (Hillman and Dalziel, 2003) to them in the form of capabilities. This has been demonstrated in the execution of corporate strategies (Westphal and Frederickson, 2001; Kroll et al., 2008; McDonald et al., 2008), professional expertise (Agrawal and Knoeber, 2001), and directors' skills, reputations, and connections (Brickley, Linck, and Coles, 1999; Fich, 2005). These points are echoed in RBV-based research on the importance of managerial expertise (Harris and Helfat, 1997; Kor, 2003).

The union of these theoretical perspectives suggests that the combination of share ownership and experience in outside directors will make them particularly effective board members, as they will have both the motivation and the wherewithal to monitor and effectively advise top management (Jensen, 1989; Hambrick and Jackson, 2000; Kroll et al., 2008). Jensen (1993: 867) describes the archetypal director embodying this combination of characteristics as an "active investor," an individual or institution that holds large debt and/or equity positions in a company and has the expertise to participate in setting and enacting its strategic direction.

The foregoing discussion suggests that ownership and experience are jointly and severally associated with a director's effectiveness as a board member. However, this story may not be as simple as it appears. We argue that directors with significant share ownership and an absence of top-level business experience could be problematic for their boards. To understand why, it is necessary to consider three main reasons directors may be appointed to boards.

First, directors may be appointed for their capabilities, expertise, and networks (Pfeffer and Salancik, 1978; Castanias and Helfat, 1991; Hillman and Dalziel, 2003). Relevant knowledge for board members might derive from their experiences in their home industries (Kor, 
2003) and companies (Westphal and Frederickson, 2001). Similarly, the presence of directors with legal, political and financial experience has been shown to be beneficial (Agrawal and Knoeber, 2001). Finally, since individuals working in high-powered settings tend to interact with similar peers (Useem, 1984), their professional connections could also be quite valuable.

Second, directors may be appointed when they have significant ownership stakes in a company. Because their incentives are properly aligned, these directors should be good representatives of the interests of other shareholders (Hambrick and Jackson, 2000).

Third, directors may be appointed to a board because they have personal associations with a company. For example, some individuals may have social relationships with the CEO or other top managers (Carpenter and Westphal, 2001). These directors may be sympathetic to managerial interests (Wade, O’Reilly, and Chandratat, 1990) and may exhibit ingratiatory behavior that facilitates or extends their appointments (Stern and Westphal, 2010).

For some director appointments, all of these motivations are present; for others, only one or two might be at play. We are interested in directors whose appointments may be motivated by the second and third explanations, but not the first: directors who attain and retain board seats because of ownership interests and personal relationships, rather than capabilities and expertise. While such appointments may be easy to justify because of a person's shareholdings, the lack of experience may undermine any expected benefits the strong incentives could produce.

Such directors may be linked to the histories of the companies they serve, through familial relationships or long-standing corporate or social associations that have endowed them with significant shareholdings in a firm, and many of these appointments may have been made at a time when the governance climate was different than it is today. These directors may hold their board seats for a long time either because the cordiality of many board cultures makes it difficult 
to remove directors (so long as they are not too disruptive), or worse, because entrenched managers try to keep such directors to limit outside influence and preserve their discretion.

Just as the literature on family firms has established that descendants of company founders are not well-suited to be running those firms (Morck, Shleifer, and Vishny, 1988; Villalonga and Amit, 2006), directors who are appointed to boards due to their shareholdings and historical connections may not be qualified to hold those seats. Even though these directors may have ownership stakes that are larger than those of other individual shareholders, their inexperience might limit their ability to contribute meaningfully to boardroom deliberations.

A lack of top-level business experience may compromise these directors' contributions in another way as well. If such directors do not have the background or skills that would make them attractive candidates for other top-flight boards, they may feel a greater sense of appreciation for the opportunity to serve on the focal board. That, in turn, could translate into heightened loyalty or social obligation to support current management (Wade et al., 1990).

It is important to consider how this lack of high-level experience and heightened loyalty might play itself out, and how the influence of these directors might be made manifest. The most obvious way would be through strong direct actions-advocacy for certain points of view, or a stubborn resistance to change. While some of this may occur, it is unlikely that one or two such directors could regularly persuade a host of more experienced directors to go along with them.

Rather, these directors' impact may be due to less confrontational behavior: reflexively voting in favor of proposals, diluting the quality of deliberations, and contributing to a board culture that cares more about cordiality and support of management than rigorous, informed oversight. In such a context, these directors' greatest impact may come not from arguing against others' ideas, but from not contributing enough good ideas. This suggests that one of the greatest 
costs of these directors may be the opportunity cost of having directors who could contribute better ideas, monitor management, and advocate more effectively for shareholders.

H1. A firm with at least one outside director who has a large ownership stake but lacks top-level business experience will have lower value than a firm with no such directors.

In boardrooms where nine to twelve directors must make value-maximizing decisions, every board seat counts. While the presence of one outside director who has a large ownership stake but lacks top-level business experience may be associated with lower firm value, this effect should worsen in the number of such directors, as their combined influence on boardroom culture and deliberations should be more pronounced. The opportunity cost of multiple such directors should also be larger, as fewer seats are available for more qualified directors.

H2. Firm value will decline in the number of outside directors on a firm's board who have significant ownership stakes but lack top-level business experience.

The dynamic implication of the first two hypotheses is that the departure from a company’s board of one or more directors who have large ownership stakes but lack top-level business experience should be associated with higher firm value. Not only might the departure of such directors liberate board seats for more qualified directors to occupy, it could also amend overly collegial cultures, paving the way for more candid and thoughtful deliberations.

H3. Firm value will increase when an outside director who has a significant ownership stake but lacks top-level business experience leaves a firm's board.

H4. The increase in firm value will be larger the more such directors leave a firm's board.

\section{Methods}

Our data consist of information about directors who served on Fortune 500 boards between 2004 and 2010. To compile the dataset, we identified the publicly-traded firms in the 
Fortune 500 in 2004, and then used Board Analyst to identify the directors who served on their boards in each year from 2004 to 2010. Board Analyst also provided basic biographical information about these directors, such as their age, tenure, employment, independence, and ownership. Our sample comprises 32,666 director-firm-year observations. We collected firmlevel data from Compustat, CRSP, Capital IQ, IRRC, and RiskMetrics.

We are interested in investigating the relationship between firm value and the presence of independent directors who own large shareholdings but lack top-level business experience.

We measure share ownership as the percentage of total shares outstanding beneficially owned by each director. Because we are interested in identifying directors who, relative to other individual shareholders, hold significant ownership stakes in their firms, we initially define a “large” ownership stake as shareholdings of at least $0.1 \%$.

To measure expertise, we heed Kroll et al.’s (2008) call for a broader conceptualization than acquisition experience and turn to three characteristics that have emerged in the literature as indicators that a director has top-level business experience: (1) founding a Fortune 500 company; (2) service, past or present, as a CEO or chairman of a Fortune 500 company; and (3) number of Fortune 500 board seats held. In addition to the frequency with which these measures have been used in the literature, they have the important added benefit of being an objective, arms-length, and replicable indicator that a director has significant high-level management expertise.

The literature has represented firm founders as having strong business experience, due to the deep internal firm knowledge and "entrepreneurial” abilities (Morck et al., 1988) that are required to start and then sustain a business. Firm value has been shown to be enhanced when founders serve as CEOs (Villalonga and Amit, 2006), and the presence of "founder-directors" on boards is associated with higher returns when those companies make acquisitions ( $\mathrm{Li}$ and 
Srinivasan, 2011). These findings suggest that founders bring a unique type of managerial experience to the boards where they serve as directors.

As the primary leaders of corporations, CEOs and chairmen (who are often retired CEOs) are thought to have substantial business experience that they bring to the companies where they serve as directors. For example, Kroll et al. (2008) find that firms' acquisition returns are higher when directors are CEOs with previous experience making acquisitions. Additionally, Kosnik (1987) finds that the greater the number of directors with executive experience, the more likely a company is to resist paying greenmail. The presence of CEO-directors on boards is generally thought to have favorable implications for the appointing firm: Fich (2005) shows that firms earn positive returns when they appoint CEOs of other companies as directors, and retired CEOs are particularly desirable candidates for board seats (Brickley et al., 1999).

Finally, the number of corporate board seats a director holds has also been viewed as reflecting that individual's top-level business experience. Several papers have shown that firm value increases when companies appoint directors who hold multiple board seats in large, public companies (Rosenstein and Wyatt, 1994), particularly when these directors have relevant strategic knowledge or expertise (Carpenter and Westphal, 2001). While being a founder or CEO of a Fortune 500 company may represent the pinnacle of business experience, being a director of multiple Fortune 500 companies is less restrictive and far more common, ${ }^{1}$ yet an unambiguous signal that a director has qualifications that are valued by more than one board.

To measure these three characteristics, we collected information on the top-level business experience for the 32,666 directors in our sample from proxy statements accessible on the SEC's EDGAR database. We determined whether these individuals had served or were serving as the CEO of a Fortune 500 firm, including their "home" institutions where they participated as board

\footnotetext{
${ }^{1}$ In any given year, approximately 35\% of all directors in our sample serve on more than one Fortune 500 board.
} 
members. We also identified whether these directors had founded a Fortune 500 company, and we collected the names of all the Fortune 500 firms where they held board seats. Using this information, we define a lack of top-level business experience by the following three criteria:

- $\quad$ Not the founder of a Fortune 500 company;

- Not the current or retired CEO or chairman of a Fortune 500 company; and

- Not a director of more than one Fortune 500 company.

In turn, we define a SOLE Director (where SOLE is an acronym for "significant ownership, low expertise”) as an outside or outside-related director who lacks top-level business experience (i.e. who meets these three criteria) and who owns shareholdings of at least $0.1 \%$.

Given that our hypotheses are about the relationship between firm value and the number of SOLE Directors serving on or departing from boards, we collapse our 32,666 director-firmyear observations into 2,798 firm-year pairs. Our dependent variable is Tobin's q, approximated as a firm’s current market-to-book ratio (Jensen and Meckling, 1976; Morck et al., 1988).

We construct several variables to represent the presence and departures of $\mathbf{S O L E}$ Directors on firms' boards. To test Hypothesis 1, we define Firm Has SOLE Director as an indicator variable taking the value one if a firm has at least one SOLE Director serving on its board, and zero otherwise. We test Hypothesis 2 using two variables: \# SOLE Directors is a count of the number of SOLE Directors on a firm's board, ranging from zero to five; Firm Has N SOLE Directors are indicator variables taking the value one if a firm has N SOLE Directors, where $\mathrm{N}$ is zero, one, two, or three (with the final category representing firms that have three or more SOLE Directors on their boards). Finally, to test Hypotheses 3 and 4, we define three analogous variables to represent departures of SOLE Directors from firms' boards: \# SOLE 
Directors Decreases, Decrease in \# SOLE Directors, and \# SOLE Directors Decreases by $N$.

These variables are summarized in Table 1.

-----Table 1 here-----

In the regressions testing the relationship between the presence of SOLE Directors and Tobin's q, we control for numerous factors that might constitute alternative explanations for our results, including the number of inside directors, dual class stock, and various measures of governance and financial conditions. Descriptions of these variables appear in Table $2 .^{2}$

-----Table 2 here-----

\section{Results}

Regressions testing our first two hypotheses appear in Table 3. All models include firm and year fixed effects, and robust standard errors are clustered by firm.

------Table 3 here-----

In Regression [II], the negative and significant coefficient on Firm Has SOLE Director suggests that the presence of SOLE Directors on a board is negatively associated with firm value, consistent with Hypothesis 1. In Regressions [III] and [IV], the coefficients on \# SOLE Directors and Firm Has N SOLE Directors are negative and significant, indicating that firm value worsens in the number of SOLE Directors, consistent with Hypothesis 2. ${ }^{3}$

Having explored the static relationship between the presence of SOLE Directors and Tobin's q, we turn our attention to the dynamic effects of SOLE Directors departing from firms' boards. Table 4 presents the results of regressions testing Hypotheses 3 and 4.

------Table 4 here-----

\footnotetext{
${ }^{2}$ Summary statistics and a correlation matrix are available upon request from the authors.

${ }^{3}$ The foregoing results are all based on SOLE Directors being defined as board members who lack top-level business experience and who own shareholdings of at least $0.1 \%$. We re-ran the regressions to test the sensitivity of our results to the use of this cutoff, and they are unchanged (results available upon request from the authors).
} 
In Regression [II], the positive and significant coefficient on \# SOLE Directors Decreases indicates that the departure of at least one SOLE Director from a firm's board is associated with higher firm value, consistent with Hypothesis 3. In Regressions [III] and [IV], the positive and significant coefficients on Decrease in \# SOLE Directors and \# SOLE Directors Decreases by $\boldsymbol{N}$ are consistent with Hypothesis 4, suggesting that firm value is higher when more SOLE Directors depart from a firm's board. This is especially true when multiple SOLE Directors depart from a firm's board, as evidenced by the fact that the coefficients on \# SOLE Directors Decreases by $N$ in Regression [IV] increase in magnitude as more SOLE Directors depart from a board. The performance improvements associated with departures of SOLE Directors are consistent with the explanation that these board members impose an opportunity cost on firms, since the seats they vacate can be filled by more qualified directors.

\section{Discussion and Conclusion}

This paper has explored how an absence of expertise, a key strategic resource for firms, may detract from the purported benefits of financial incentives. Using the boards of Fortune 500 firms as our empirical context, we find that firm value is negatively associated with the presence of directors who have large shareholdings but lack business expertise. Firm value increases following departures of such directors, especially when the number of departures is the largest.

The implications of this work are noteworthy for several reasons. For firm governance, the results challenge what appears to be a reasonably widespread but little noted practice of appointing board members whose individual shareholdings are accepted as a substitute for highlevel business expertise. Jensen (1989) made the provocative prediction that a new model of governance would emerge in boardrooms, wherein boards would be composed of directors with 
both large ownership stakes and significant business expertise: "skin in the game" as well as toplevel managerial experience. However, this prediction largely has not been borne out in practice.

Institutional investors and blockholders often hold the largest ownership positions in Fortune 500 companies and many have substantial experience in corporate oversight, yet their representatives rarely hold board seats. The absence in Fortune 500 boardrooms of the type of directors Jensen advocated for becomes even more stark and concerning when considered in conjunction with the relative frequency with which the directors studied in this paper appear on the boards of publicly traded firms. ${ }^{4}$ While the shareholdings of these directors may be large relative to those of other individual shareholders, their economic significance is dwarfed by those of institutional investors. These results raise questions about the individuals who serve on the boards of the largest corporations, as well as those who do not.

More generally, this study highlights the often ignored ceteris paribus clause of agency theory, that, all else being equal, the alignment of an agent's interests through share ownership should lead to the maximization of shareholder value. For the agents in this study, all else is not equal: their relative lack of expertise appears to undermine the purported benefits of their incentives. Further, the evidence here suggests that incentives and expertise are not simply additive: more of the former does not make up for less of the latter. An upbeat story is when agents have high levels of both incentives and expertise; a more sobering story, illustrated here, is when a paucity of experience interferes with the effectiveness of incentives.

\footnotetext{
${ }^{4}$ About 20\% of Fortune 500 firms have at least one director with significant ownership and low expertise on their boards in any given year, and up to $6 \%$ of boards have more than one such director in any given year.
} 


\section{References}

Agrawal A, Knoeber CR (2001) Do some outside directors play a political role? Journal of Law and Economics 44: 179-198.

Berle AA, Means GC (1932) The modern corporation and private property. (Harcourt, Brace, \& World, New York, NY).

Brickley JA, Linck JS, Coles JL (1999) What happens to CEOs after they retire? New evidence on career concerns, horizon problems, and CEO incentives. Journal of Financial Economics 52: 341-377.

Carpenter MA, Westphal JD (2001) The strategic context of external network ties: examining the impact of director appointments on board involvement in strategic decision making. Academy of Management Journal 44(4): 639-660.

Castanias RP, Helfat CE (1991) Managerial resources and rents. Journal of Management 17(1): 155-171.

Fich EM (2005) Are some outside directors better than others? Evidence from director appointments by Fortune 1000 firms. Journal of Business 78: 1943-1971.

Gompers P, Ishii J, Metrick A (2003) Corporate governance and equity prices. Quarterly Journal of Economics 118: 107-155.

Hambrick DC, Jackson EM (2000) Outside directors with a stake: the linchpin in improving governance. California Management Review 42(4): 108-127.

Harris D, Helfat C (1997) Specificity of CEO human capital and compensation. Strategic Management Journal 18: 895-920.

Hillman AJ, Dalziel T (2003) Boards of directors and firm performance: integrating agency and resource dependence perspectives. Academy of Management Review 28(3): 383-396.

Jensen MC (1989) Eclipse of the public corporation. Harvard Business Review Sept-Oct: 61-73.

Jensen MC (1993) The modern industrial revolution, exit, and the failure of internal control systems. Journal of Finance 48: 831-880.

Jensen MC, Meckling WH (1976) Theory of the firm: managerial behavior, agency costs, and ownership structure. Journal of Financial Economics 3: 305-360.

Johnson RA, Hoskisson RE, Hitt MA (1993) Board of director involvement in restructuring: the effects of board versus managerial controls and characteristics. Strategic Management Journal 14: 33-50. 
Kor YY (2003) Experience-based top management team competence and sustained growth. Organization Science 14(6): 707-719.

Kosnik RD (1987) Greenmail: a study of board performance in corporate governance. Administrative Science Quarterly 32(2): 163-185.

Kroll M, Walters BA, Wright P (2008) Board vigilance, director experience, and corporate outcomes. Strategic Management Journal 29: 363-382.

Li F, Srinivasan S (2011) Corporate governance when founders are directors. Journal of Financial Economics 102(2): 454-469.

McDonald ML, Westphal JD, Graebner ME (2008) What do they know? The effects of outside director acquisition experience on firm acquisition performance. Strategic Management Journal 29: $1155-1177$.

Morck R, Shleifer A, Vishny RW (1988) Management ownership and market valuation: an empirical analysis. Journal of Financial Economics 20: 293-315.

Penrose ET (1959) The theory of the growth of the firm. (John Wiley, New York).

Pfeffer J, Salancik G (1978) The external control of organizations: a resource dependence perspective. (Harper \& Row, New York, NY).

Rosenstein S, Wyatt JG (1994) Shareholder wealth effects when an officer of one corporation joins the board of directors of another. Managerial and Decision Economics 15: 317-327.

Stern I, Westphal JD (2010) Stealthy footsteps to the boardroom: executives' backgrounds, sophisticated interpersonal influence behavior, and board appointments. Administrative Science Quarterly 55(2): 278-319.

Useem M (1984) The inner circle. (Oxford University Press, Oxford, UK).

Villalonga B, Amit R (2006) How do family ownership, control, and management affect firm value? Journal of Financial Economics 80: 385-417.

Wade J, O’Reilly III CA, Chandratat I (1990) Golden parachutes: CEOs and the exercise of social influence. Administrative Science Quarterly 35(4): 587-603.

Wernerfelt B (1984) A resource-based view of the firm. Strategic Management Journal 5: 171180.

Westphal JD, Frederickson JW (2001) Who directs strategic change? Director experience, the selection of new CEOs, and change in corporate strategy. Strategic Management Journal 22: 1113-1137. 
Table 1. Descriptions of key independent variables

\begin{tabular}{|c|c|}
\hline Director-Level Construct & Description \\
\hline SOLE Director & $\begin{array}{l}\text { Indicator variable taking the value one if an outside or outside-related director: } \\
\text { (1) is not the founder of a Fortune } 500 \text { company, } \\
\text { (2) is not the current or retired CEO or chairman of a Fortune } 500 \text { company, } \\
\text { (3) is not a director of more than one Fortune } 500 \text { company, and } \\
\text { (4) owns shareholdings of at least } 0.1 \%\end{array}$ \\
\hline Firm-Level Variables & Description \\
\hline Firm Has SOLE Director & $\begin{array}{l}\text { Indicator variable taking the value one if a firm has at least one SOLE director on } \\
\text { its board }\end{array}$ \\
\hline \# SOLE Directors & Number of SOLE directors on a company's board \\
\hline Firm Has N SOLE Directors & $\begin{array}{l}\text { Indicator variables taking the value one if a firm has } \mathrm{N} \text { SOLE directors on its board, } \\
\mathrm{N}=\left[0,1,2,3^{+}\right]\end{array}$ \\
\hline \# SOLE Directors Decreases & $\begin{array}{l}\text { Indicator variable taking the value one if the number of SOLE directors on a firm's } \\
\text { board decreases in a given year }\end{array}$ \\
\hline Decrease in \# SOLE Directors & Decrease in the number of SOLE directors on a firm's board in a given year \\
\hline \# SOLE Directors Decreases by N & $\begin{array}{l}\text { Indicator variables taking the value one if the number of SOLE directors on a firm's } \\
\text { board decreases by } N \text { in a given year, } N=\left[0,1,2,3^{+}\right]\end{array}$ \\
\hline
\end{tabular}




\section{Table 2. Descriptions of control variables}

\begin{tabular}{|c|c|}
\hline Variable & Description \\
\hline Dual Class Stock & Indicator variable taking the value one if a firm has dual class stock \\
\hline Board Ownership & Percentage of total shares outstanding owned by members of the board of directors \\
\hline G-Index & Count of $N$ provisions a firm has in place that weaken shareholder rights, $N=[0,1,2, \ldots 8,9]^{+}$ \\
\hline Dual CEO-Chair & Indicator variable taking the value one if the same person is both CEO and chairman \\
\hline Founder on Board & Indicator variable taking the value one if the firm's founder is a director \\
\hline Board Size & Number of directors on the board \\
\hline Total Insiders & Number of inside directors on the board \\
\hline Dividends/BV Equity & Ratio of dividend payments to the book value of equity \\
\hline Debt/MV Equity & Ratio of book value of debt to market value of equity \\
\hline Capex/Net PPE & Ratio of capital expenditures to property, plant and equipment \\
\hline $\ln$ (Total Assets) & Natural log of total assets \\
\hline Beta & 12-month correlation of stock returns to market returns \\
\hline \multicolumn{2}{|c|}{$\begin{array}{l}\text { This variable is an approximation of the Gompers et al. (2003) G-Index. The original G-Index awarded firms a point for each of } 24 \text { provisions } \\
\text { they had in place that weakened shareholder rights. However, following its acquisition of IRRC (the original provider of the data on these } 24 \\
\text { provisions), RiskMetrics only compiled data on a subset of nine of these provisions: fair price laws, supermajority voting rights, unequal voting } \\
\text { rights, poison pills, confidential voting rights, cumulative voting rights, golden parachutes, limitations on shareholders' ability to amend the firm's } \\
\text { charter, and limitations on shareholders' ability to amend the firm's bylaws. Thus, the G-Indexused in this paper is a count of the number of these } \\
\text { nine provisions a firm has in place. Importantly, for the three years in which IRRC and RiskMetrics both collected governance data (2004-2006), } \\
\text { the correlation between the Gompers et al. (2003) G-Index and the G-Indexused in this paper was 0.78, suggesting that our approximation is a } \\
\text { reasonable one. }\end{array}$} \\
\hline
\end{tabular}


Table 3. SOLE Directors and firm value

\begin{tabular}{|c|c|c|c|c|}
\hline Dependent Variable: Tobin's q & (I) & (II) & (III) & (IV) \\
\hline Firm Has SOLE Director & & $\begin{array}{c}-0.070^{* *} \\
(0.036)\end{array}$ & & \\
\hline \# SOLE Directors & & & $\begin{array}{c}-0.037 * * \\
(0.017)\end{array}$ & \\
\hline Firm Has 1 SOLE Director & & & & $\begin{array}{c}-0.077 * * \\
(0.038)\end{array}$ \\
\hline Firm Has 2 SOLE Directors & & & & $\begin{array}{c}-0.102 * * \\
(0.044)\end{array}$ \\
\hline Firm Has 3+ SOLE Directors & & & & $\begin{array}{c}-0.122 * * \\
(0.064)\end{array}$ \\
\hline Dual Class Stock & $\begin{array}{c}0.210^{*} \\
(0.124)\end{array}$ & $\begin{array}{c}0.209^{*} \\
(0.124)\end{array}$ & $\begin{array}{c}0.209 * \\
(0.125)\end{array}$ & $\begin{array}{c}0.209 * \\
(0.123)\end{array}$ \\
\hline Board Ownership & $\begin{array}{l}0.270 \\
(0.296)\end{array}$ & $\begin{array}{c}0.062 \\
(0.330)\end{array}$ & $\begin{array}{l}0.106 \\
(0.321)\end{array}$ & $\begin{array}{l}0.081 \\
(0.327)\end{array}$ \\
\hline G-Index & $\begin{array}{c}-0.004 \\
(0.008)\end{array}$ & $\begin{array}{c}-0.005 \\
(0.008)\end{array}$ & $\begin{array}{c}-0.005 \\
(0.008)\end{array}$ & $\begin{array}{c}-0.005 \\
(0.008)\end{array}$ \\
\hline Dual CEO-Chair & $\begin{array}{c}-0.026 \\
(0.035)\end{array}$ & $\begin{array}{c}-0.024 \\
(0.035)\end{array}$ & $\begin{array}{c}-0.025 \\
(0.035)\end{array}$ & $\begin{array}{r}-0.022 \\
(0.035)\end{array}$ \\
\hline Founder on Board & $\begin{array}{l}0.056 \\
(0.078)\end{array}$ & $\begin{array}{l}0.040 \\
(0.081)\end{array}$ & $\begin{array}{l}0.046 \\
(0.081)\end{array}$ & $\begin{array}{l}0.039 \\
(0.080)\end{array}$ \\
\hline Board Size & $\begin{array}{l}0.002 \\
(0.007)\end{array}$ & $\begin{array}{l}0.003 \\
(0.007)\end{array}$ & $\begin{array}{l}0.003 \\
(0.008)\end{array}$ & $\begin{array}{l}0.003 \\
(0.007)\end{array}$ \\
\hline Total Insiders & $\begin{array}{c}0.042 * * \\
(0.018)\end{array}$ & $\begin{array}{c}0.039 * * \\
(0.018)\end{array}$ & $\begin{array}{c}0.039 * * \\
(0.018)\end{array}$ & $\begin{array}{c}0.039 * * \\
(0.018)\end{array}$ \\
\hline Dividends/BV Equity & $\begin{array}{c}0.630 * * \\
(0.248)\end{array}$ & $\begin{array}{c}0.618^{* *} \\
(0.247)\end{array}$ & $\begin{array}{c}0.622^{* *} \\
(0.248)\end{array}$ & $\begin{array}{c}0.606^{* *} \\
(0.245)\end{array}$ \\
\hline Debt/MV Equity & $\begin{array}{c}0.004 \\
(0.031)\end{array}$ & $\begin{array}{c}0.002 \\
(0.031)\end{array}$ & $\begin{array}{l}0.002 \\
(0.031)\end{array}$ & $\begin{array}{l}0.002 \\
(0.031)\end{array}$ \\
\hline Capex/Net PPE & $\begin{array}{c}2.020^{* * *} \\
(0.239)\end{array}$ & $\begin{array}{c}2.008^{* * *} \\
(0.237)\end{array}$ & $\begin{array}{c}2.005^{* * *} \\
(0.237)\end{array}$ & $\begin{array}{c}2.014 * * * \\
(0.236)\end{array}$ \\
\hline $\ln$ (Total Assets) & $\begin{array}{c}-0.464 * * * \\
(0.079)\end{array}$ & $\begin{array}{c}-0.467 * * * \\
(0.079)\end{array}$ & $\begin{array}{c}-0.465 * * * \\
(0.079)\end{array}$ & $\begin{array}{c}-0.466 * * * \\
(0.079)\end{array}$ \\
\hline Beta & $\begin{array}{c}-0.033^{*} \\
(0.019)\end{array}$ & $\begin{array}{c}-0.033^{*} \\
(0.020)\end{array}$ & $\begin{array}{r}-0.032 \\
(0.020)\end{array}$ & $\begin{array}{c}-0.034^{*} \\
(0.019)\end{array}$ \\
\hline Constant & $\begin{array}{c}5.640 * * * \\
(0.768)\end{array}$ & $\begin{array}{c}5.678^{* * *} \\
(0.770)\end{array}$ & $\begin{array}{c}5.656 * * * \\
(0.769)\end{array}$ & $\begin{array}{c}5.674 * * * \\
(0.771)\end{array}$ \\
\hline Firm Fixed Effects & Yes & Yes & Yes & Yes \\
\hline Year Fixed Effects & Yes & Yes & Yes & Yes \\
\hline Observations & 2,201 & 2,201 & 2,201 & 2,201 \\
\hline$R^{2}$ & 0.2188 & 0.2210 & 0.2201 & 0.2217 \\
\hline
\end{tabular}

Robust standard errors clustered by firm in parentheses.

$* * * \mathrm{p}<0.01, * * \mathrm{p}<0.05, * \mathrm{p}<0.1$ 
Table 4. Firm value following departures of SOLE Directors

\begin{tabular}{|c|c|c|c|c|}
\hline Dependent Variable: Tobin's q & (I) & (II) & (III) & (IV) \\
\hline \# SOLE Directors Decreases & & $\begin{array}{c}0.069 * * \\
(0.035)\end{array}$ & & \\
\hline Decrease in \# SOLE Directors & & & $\begin{array}{c}0.058 * * \\
(0.027)\end{array}$ & \\
\hline \# SOLE Directors Decreases by 1 & & & & $\begin{array}{c}0.078 * * \\
(0.039)\end{array}$ \\
\hline \# SOLE Directors Decreases by 2 & & & & $\begin{array}{c}0.174 * * \\
(0.084)\end{array}$ \\
\hline \# SOLE Directors Decreases by 3+ & & & & $\begin{array}{c}0.299 * * \\
(0.133)\end{array}$ \\
\hline Dual Class Stock & $\begin{array}{c}0.210^{*} \\
(0.124)\end{array}$ & $\begin{array}{l}0.060 \\
(0.076)\end{array}$ & $\begin{array}{l}0.058 \\
(0.075)\end{array}$ & $\begin{array}{l}0.060 \\
(0.076)\end{array}$ \\
\hline Board Ownership & $\begin{array}{l}0.270 \\
(0.296)\end{array}$ & $\begin{array}{l}0.369 \\
(0.284)\end{array}$ & $\begin{array}{l}0.277 \\
(0.276)\end{array}$ & $\begin{array}{l}0.247 \\
(0.277)\end{array}$ \\
\hline G-Index & $\begin{array}{c}-0.004 \\
(0.008)\end{array}$ & $\begin{array}{c}-0.004 \\
(0.007)\end{array}$ & $\begin{array}{c}-0.004 \\
(0.007)\end{array}$ & $\begin{array}{c}-0.004 \\
(0.007)\end{array}$ \\
\hline Dual CEO-Chair & $\begin{array}{c}-0.026 \\
(0.035)\end{array}$ & $\begin{array}{r}-0.011 \\
(0.039)\end{array}$ & $\begin{array}{c}-0.011 \\
(0.039)\end{array}$ & $\begin{array}{r}-0.010 \\
(0.039)\end{array}$ \\
\hline Founder on Board & $\begin{array}{l}0.056 \\
(0.078)\end{array}$ & $\begin{array}{l}0.061 \\
(0.073)\end{array}$ & $\begin{array}{l}0.059 \\
(0.074)\end{array}$ & $\begin{array}{l}0.057 \\
(0.073)\end{array}$ \\
\hline Board Size & $\begin{array}{l}0.002 \\
(0.007)\end{array}$ & $\begin{array}{r}-0.001 \\
(0.008)\end{array}$ & $\begin{array}{r}-0.001 \\
(0.008)\end{array}$ & $\begin{array}{r}-0.000 \\
(0.008)\end{array}$ \\
\hline Total Insiders & $\begin{array}{c}0.042 * * \\
(0.018)\end{array}$ & $\begin{array}{c}0.059 * * * \\
(0.019)\end{array}$ & $\begin{array}{c}0.059 * * * \\
(0.019)\end{array}$ & $\begin{array}{c}0.058 * * * \\
(0.019)\end{array}$ \\
\hline Dividends/BV Equity & $\begin{array}{c}0.630 * * \\
(0.248)\end{array}$ & $\begin{array}{c}0.590 * * \\
(0.261)\end{array}$ & $\begin{array}{c}0.585 * * \\
(0.260)\end{array}$ & $\begin{array}{c}0.577 * * \\
(0.262)\end{array}$ \\
\hline Debt/MV Equity & $\begin{array}{c}0.004 \\
(0.031)\end{array}$ & $\begin{array}{l}0.014 \\
(0.032)\end{array}$ & $\begin{array}{l}0.015 \\
(0.032)\end{array}$ & $\begin{array}{l}0.013 \\
(0.032)\end{array}$ \\
\hline Capex/Net PPE & $\begin{array}{c}2.020^{* * *} \\
(0.239)\end{array}$ & $\begin{array}{c}2.133^{* * *} \\
(0.235)\end{array}$ & $\begin{array}{c}2.132^{* * *} \\
(0.235)\end{array}$ & $\begin{array}{c}2.142^{* * *} \\
(0.235)\end{array}$ \\
\hline $\ln$ (Total Assets) & $\begin{array}{c}-0.464 * * * \\
(0.079)\end{array}$ & $\begin{array}{c}-0.563 * * * \\
(0.080)\end{array}$ & $\begin{array}{c}-0.562 * * * \\
(0.080)\end{array}$ & $\begin{array}{c}-0.561 * * * \\
(0.080)\end{array}$ \\
\hline Beta & $\begin{array}{c}-0.033^{*} \\
(0.019)\end{array}$ & $\begin{array}{c}-0.100 * * * \\
(0.025)\end{array}$ & $\begin{array}{c}-0.099 * * * \\
(0.025)\end{array}$ & $\begin{array}{c}-0.099 * * * \\
(0.025)\end{array}$ \\
\hline Constant & $\begin{array}{c}5.640^{* * *} \\
(0.768)\end{array}$ & $\begin{array}{c}6.689 * * * \\
(0.799)\end{array}$ & $\begin{array}{c}6.672^{* * *} \\
(0.797)\end{array}$ & $\begin{array}{c}6.664^{* * *} \\
(0.797)\end{array}$ \\
\hline Firm Fixed Effects & Yes & Yes & Yes & Yes \\
\hline Year Fixed Effects & Yes & Yes & Yes & Yes \\
\hline Observations & 2,201 & 1,745 & 1,745 & 1,745 \\
\hline$R^{2}$ & 0.2188 & 0.2657 & 0.267 & 0.2679 \\
\hline
\end{tabular}

Robust standard errors clustered by firm in parentheses.

*** $\mathrm{p}<0.01,{ }^{* *} \mathrm{p}<0.05,{ }^{*} \mathrm{p}<0.1$ 